\title{
PENGEMBANGAN BUKU AJAR FISIKA BERBASIS KONTEKSTUAL PADA MATERI MEDAN MAGNETIK SISWA KELAS XII SMA NEGERI 2 MUARA BELITI
}

\author{
Dela Aryansi ${ }^{1}$, Yaspin Yolanda ${ }^{2}$ \\ delaaryansi02@gmail.com \\ ${ }^{1,2}$ Program Studi Pendidikan Fisika STKIP PGRI Lubuklinggau, Sumatera Selatan, Indonesia
}

Received: 26 Oktober 2020

Revised: 30 November 2020

Accepted: 8 Desember 2020

\begin{abstract}
This research aims to develop a textbook of physics based on contextual magnetic field material in class XII students of SMA Negeri 2 Muara Beliti. The research method in this research is Research and Development, while the development model used is ADDIE with 5 stages of Analyze, design, devlopment, implementation and evaluation. The population in this study was class XII IPA 3 with 28 students. The sampling technique used positive sampling using 6 samples. Data collection techniques in this study used interviews, observation, diagnostic test questions, expert validation questionnaires, teacher response questionnaires, student response questionnaires and contextualbased physics textbooks. The results of the validation questionnaire data analysis with 3 validator experts were the results of the validation of the physics lecturer material 42, the results of the validation of the physics teacher material with a score of 46 . The results of the validation of the linguists got a score of 18, the results of the validation of the media expert got a score of 35, so the final score obtained after validation of 35 in the very good category, the results of the 6 student response questionnaires obtained a score of 3.7 with the category of strongly agree and the results of the questionnaire response of the teacher and students got a score of 3.6 with the category of strongly agree. The results of competency test scores to support practicality obtained competency test scores obtained by an average of $80.3 \%$ complete reaching $\geq 75$. So it can be said that the Textbook of Physics Based on Contextual Magnetic Field Material in Class XII Students of SMA Negeri 2 Muara Beliti is Valid and Practical .
\end{abstract}

\begin{abstract}
Abstrak: Penelitian ini bertujuan mengembangan buku ajar fisika Berbasis Kontekstual Materi Medan Magnetik pada Siswa Kelas XII SMA Negeri 2 Muara Beliti. Metode penelitian dalam penelitian ini yaitu Research and Developmen, sedangkan model pengembangan yang digunakan adalah ADDIE dengan 5 tahapan Analyze, design, devlopment, inplementation dan evaluation. Populasi dalam penelitian ini adalah kelas XII IPA 3 dengan 28 orang siswa. Teknik pengambilan sampling menggunakan porposive sampling yang menggunakan 6 orang sampel. Teknik pengumpulan data dalam penelitian ini menggunakan wawacara, observasi, soal tes diagnosis, angket validasi ahli, angket respon guru, angket respon siswa dan buku ajar Fisika Berbasis Kontekstual. Hasil analisis data angket validasi dengan 3 ahli validator yaitu hasil validasi materi dosen fisika 42, hasil validasi materi guru fisika dengan skor 46. Hasil validasi ahli bahasa mendapatkan skor sebesar 18, hasil validasi ahli media mendapatkan skor sebesar 35, sehingga skor akhir yang didapatkan setelah validasi sebesar 35 dengan katagori sangat baik, hasil angket respon 6 siswa diperoleh skor sebesar 3,7 dengan katagori sangat setuju dan hasil angket respon guru dan siswa mendapat skor sebesar 3,6 dengan katagori sangat setuju. hasil nilai uji kompetensi untuk menunjang kepraktisan memperoleh nilai uji kompetensi yang didapat rata-rata 80,3\% tuntas mencapai $\geq 75$. Sehingga dapat dikatakan bahwa Buku Ajar Fisika Berbasis Kontekstual Materi Medan Magnetik pada Siswa Kelas XII SMA Negeri 2 Muara Beliti Telah Valid Dan Praktis.
\end{abstract}

Kata kunci: Pengembangan, Buku, Kontekstual Materi Medan Magnetik. 


\section{PENDAHULUAN}

Negara Indonesia ini adalah salah satu negara yang sedang berkembang sangat baik dan pesat salah satu cara yang dapat digunakan untuk memajukan negara indonesia yaitu melalui sektor pendidikan. Menurut kurniawan (2017) pendidikan adalah salah satu kegiatan yang kegiatan yang berguna untuk mengoktimalkan pengembangan potensi pada peserta didik, kecakapan, dan karakteristik pribadi pada masing-masing peserta didik, dari sebuah pendidikan, maka negara Indonesia akan menghasilkan generasi dan tenaga-tenaga yang berkualitas yang berguna untuk memajukan bangsa. Oleh sebab itu, pemerintah selalu berupaya untuk selalu meningkatkan mutu pendidikan yang ada di indonesia.

Banyak faktor yang bisa dilakukan pemerintah untuk meningkatkan kualitas dan mutu pendidikan yang ada di Indonesia. Salah satu faktornya yaitu pada tenaga pendidik, siswa, serta alat pendidikan itu sendiri. Banyak yang beranggapan bahwa sebenarnya alat pendidikan tidak berpengaruh dalam meningkatkan mutu pendidikan, namu pada hakikatnya bahwa tanpa alat pendidikan maka pendidikan tidak akan berjalan dengan mulus, yang dimaksud dengan alat pendidikan disini yaitu berupa sarana dan prasarana yang ada disekolah, serta kurikulum yang diberlakukan di sekolah (Arini, W., \& Lovisia, E, 2019).

Menurut UU nomor 20 tahun 2003 kurikulum adalah seperangkat rencana dan beberapa peraturan yang berisi tujuan, isi, dan bahan pelajaran serta cara yang dapat digunakan sebagai pedoman dalam penyelenggaraan kegiatan pembelajaran guna mencapai tujuan pendidikan tertentu. Kurikulum adalah faktor yang sangat berpengaruh dalam peningkatan mutu pendidikan. Kurikulum menjadikan pembelajaran lebih sistematis dan terarah. Tanpa adanya kurikulum, maka pencapaian tujuan pendidikan akan sangat sulit untuk dicapai. Dalam kurikulum selalu ada pembaruan guna meningkatkan mutu pendidikan, kurikulum yang baru saat ini adalah kurikulum 2013. Kurikulum 2013 saat ini merupakan kurikulum yang lebih mengedepankan pada keaktifan dan kemandirian siswa dalam proses pembelajaran. Siswa akan lebih aktif dan mandiri jika materi dalam proses pembelajaran berkaitan dalam kehidupan nyata yang ada. Maka dari itu, model pembelajaran yang cocok diterapkan pada kondisi saat ini yaitu model pembelajaran kontekstual. Pembelajaran kontekstual adalah konsep belajar dimana guru menghadirkan dunia nyata kedalam kelas dan mendorong siswa membuat hubungan antara pengetahuan yang dimiliki dengan penerapannya dalam kehidupan mereka sehari-hari, sementara siswa memperoleh pengetahuan dan keterampilan dari konteks yang terbatasi sedikit demi sedikit dan dari proses mengkonstruksi sendiri sebagai bekal untuk memecahkan masalah dalam kehidupannya sebagai anggota masyarakat. Dengan 
pembelajaran kontekstual ini maka siswa akan berkerja dan mengalami, bukan transper pengetahuan dari guru kesiswa semata. Strategi lebih dipentingkan dari pada hasilnya. Sehingga pengetahuan dan keterampilan yang diperoleh datang dari proses penemuan sendiri dan bukan kata guru (Ariani, T., \& Yolanda, Y, 2019).

Agar dapat berjalan lancar sehingga peserta didik dapat optimal dalam proses pembelajaran. Sehingga setelah pembelajaran siswa diharapkan memahami dan mampu mengkaitkan materi pembelajaran dalam kehidupan sehari-hari bukan sekedar menghapal. Dalam kegiatan pembelajaran selain penggunaan pendekatan yang tepat, komponen pembelajaran yang digunakan untuk menunjang keberhasilan kegiatan belajar mengajar juga harus tepat, salah satu sarana dan prasarana yang tepat menunjang proses pembelajaran yaitu salah satunya buku ajar (Ariani, T, 2017).

Menurut Prastowo (2014) pada umumnya buku ajar adalah suatu bahan ajar hasil dari seseorang pengarang atau yang berasal dari suatu tim pengarang dimana dalam penyusunannya dilakukan berdasarkan atas kurikulum ataupun tafsiran dari kurikulum yang berlaku. Buku ajar dapat membantu guru pada saat proses mengajar dan siswa dalam proses belajar. Dengan adanya buku ajar, guru tidak terlalu banyak menyajikan untuk membimbing belajar siswa. Bagi siswa, dengan adanya buku ajar akan membuat siswa lebih mandiri dalam belajar dan mengurangi dampak ketergantungan pada gurunya, sehingga hal tersebut dapat mendukung prinsip belajar sepanjang hayat atau life long education.

Berdasarkan hasil observasi di SMA Negeri 2 Muara Beliti untuk mendapatkan analisa kebutuhan atau analyze, dimulai dari wawancara bersama guru dan siswa didapatkan sebuah informasi. Mengenai kriteria jumlah kriteria ketuntasan maksimal fisika di SMA Negeri 2 Muara Beliti adalah 75, model pembelajaran yang digunakan dalam proses pembelajaran fisika di SMA Negeri 2 Muara Beliti tersebut sudah masuk ke kurikulum 2013 namun untuk pelaksanaan pembelajaran masih menggunakan metode konvensial (ceramah).

Pada proses pembelajaran tidak pernah melaksanakan pratikum, kendala jarang melaksanakan praktikum yang ditemukan adalah kurangnya fasilitas yang memadai, keadaan siswa dalam pembelajaran masih bersifat monoton atau pasif. Pembelajaran fisika selalu diajarakan dengan metode konvensional sehingga kebermanfaatan materi dalam kehidupan sehari-hari tidak terlihat, sehingga penggunaan Konteksual sangat mendudukung dalam pengembangan buku ajar materi medan magnetik terlihat pada pengembangan buku ajar materi medan magnetik ini pada tahapan kontekstual dan penerapanya seperti mengkonstruktivisme permasalahan tentang magnet, siswa menemukan pengetahuan tentang 
medan magnetik melalui praktikum, bertanya tentang materi pemuaian, modeling pada buku ajar ini ialah menyusun alat praktikum magnet, refleksi ialah tahapan perulangan pemikiran pada buku refleksi dilihat dri latihan soal dan pengerjaan tugas, dan sintaks terakhir CTL ialah penilaian sebenarnya dilihat dari hasil belajar kognitif pengerjaan uji kompetensi. Untuk penggunaan buku ajar pun tidak ada. Proses pembelajaran siswa menggunakan buku paket yang diterima dari pemerintah telah sesuai dengan kurikulum yang digunakan di sekolah tersebut, selain wawancara peneliti melakukan tes diagnosis guna menambah informasi yang diperlukan bagi peneliti, yang dilaksakan menggunakan 9 siswa dengan tingkat 3 kemampuan yaitu, tinggi, sedang, dan rendah dan didapatlah hasil bahwa dari ke 9 siswa yang melakukan tes diagnosis tersebut hanya 2 siswa yang mendapat nilai 72 sedangkan untuk 7 siswa lain mendapat nilai 60 kebawah. Peneliti saat observasi kemarin juga mengamati tingkah laku siswa saat proses pembelajaran yang cenderung monoton, prilaku siswa terlihat merasa bosan dengan pembelajaran dan pasif. Bahan ajar yang mereka gunakan adalah buku paket yang dipinjam dari sekolah tersebut dan untuk penggunaanya pun mereka hanya menggunaan saat ada tugas saja, bentuknya seperti buku pelajaran pada biasanya.. Setelah peneliti selesai observasi, didapatlah hasil yang didapatkan sebuah informasi bahwa tingkat pemahaman siswa terhadap sebuah pelajaran sangat dipengaruhi oleh motivasi, cara belajar, bahan pembelajaran, pengolahan kelas dan model yang digunakan yang mampu membuat siswa aktif, kreatif dan mandiri. Salah satu upaya untuk menyelesaikan masalah tersebut adalah seorang peneliti yang mengembangkan sebuah bahan ajar berupa buku ajar fisika berbasis kontekstual materi medan magnetik di SMA Negeri 2 Muara Beliti, secara ringkas dan menarik yang nantinya akan digunakan oleh peserta didik secara mandiri menemukan dan menyerap informasi, serta dapat menujang proses pembelajaran pada kurikulum 2013. Prastowo (2014) mengatakan sebagaimana salah satu jenis bahan ajar cetak, buku ajar memiliki sejumlah karakteristik yang membedakannya dengan bahan ajar cetak lainnya.

Dalam pemecahan masalah adanya penalaran yang bersifat ilmiah yang didasarkaan dengan kehidupan nyata yang ada disekitar dan mempermudah siswa dalam proses pembelajaran seperti halnya buku ajar berbasis kontekstual. Buku ajar merupakan salah satu bahan ajar yang dibutuhkan dalam proses pembelajaran materi fisika, hal ini dikarenakan saat proses pembelajaran fisika tidak hanya sekedar teoritis namun ada juga eksperimen didalamnya namun pada era saat ini mental anak menipis sehingga siswa jarang untuk tertantang mempelajari materi fisika, karena siswa beranggapan bahwa materi pelajaran fisika itu sulit, kesulitan siswa disini juga disebabkan karena bahan ajar yang digunakan sulit 
dipahami oleh siswa, kurangnya desain dalam bahan ajar tersebut dan sedikit aktivitas eksperimen dalam bahan ajar tersebut serta kurangnya sumber belajar lainnya. Buku ajar fisika yang disusun berdasarkan pendekatan kontekstual, merupakan suatu strategi pembelajaran yang menghubungkan antara konten pelajaran dengan kondisi kehidupan sehari-hari yang akan mendorong peserta didik mengaitkan antara pengetahuan dan pengalaman yang didapatnya sebagai anggota keluarga, warga negara, dan dunia pendidikan salah satu pendekatan pembelajaran inovatif ialah pedekatan Contextual Teaching and Learning atau sering disebut juga kontekstual, pendekatan kontekstual memiliki tujuh komponen utama yaitu kontruktivisme, menemukan, bertanya, masyarakat belajar, pemodelan, dan penilaian yang sebenarnya. Buku ajar berbasis kontekstual merupakan buku ajar yang berisikan, materi pembelajaran dengan bahasa yang mudah dipahami siswa, panduan praktikum, disusun secara lengkap berdasarkan pendekatan kontesktual melalui pendekatan ini siswa diharapkan dapat menemukan materi langsung berkaitan dengan kehidupan sehari-hari. maka tujuan penelitan yang ingin dicapai Aadalah untuk a). Untuk mengetahui cara mengembangkan Buku Ajar Fisika Berbasis Kontekstual Pada Materi Medan Magnetik Siswa Kelas XII SMA Negeri 2 Muara Beliti. b). Untuk mengetahui Buku Ajar Fisika Berbasis Kontekstual apakah telah memenuhi sasaran Kevalidan dan Kepraktisan pada Siswa Kelas XII SMA Negeri 2 Muara Beliti.

\section{METODE PENELITIAN}

Metode yang digunakan dalam penelitian ini yaitu Research and Development atau penelitian dan pengembangan adalah sebuah metode penelitian yang digunakan untuk menghasilkan sebuah produk tertentu, dan menguji kevalidan dan kepraktisan produk tersebut. Dalam penelitian ini untuk mengembangkan sebuah buku bebasis kontekstual pada materi medan magnetik menggunakan model pengembangan ADDIE. dimana dalam penelitian ini terdapat 5 langkah yang terdapat dalam model pengembangan ADDIE. Adapun langkah dari model pengembangan ADDIE terdapat 5 langkahn yaitu: Analyze, design, develop, Implement dan Evaluate. Rancangan dalam penelitian ini menggunakan desain purposive sampling. Adapun buku ajar dengan menggunakan model pengembangan ADDIE dapat dilihat seperti pada gambar 1 . 


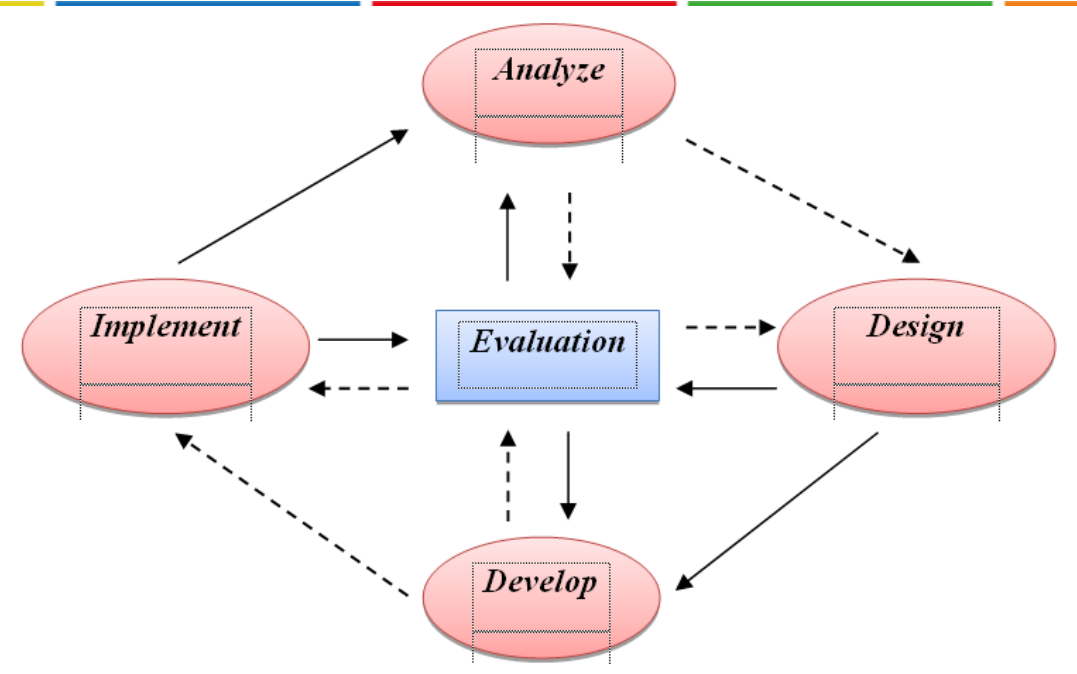

Gambar 1. Desain model pengembangan ADDIE

Populasi dalam penelitian ini adalah seluruh siswa kelas XII IPA 3 SMA Negeri 2 Muara Beliti tahun pelajaran 2020/2021. Peneliti melakukan 1 tahap pengujian yaitu dengan menggunakan perorangan peneliti menggunakan angket dengan 6 orang siswa kelas XII IPA 3. Angket ini berisi 10 pernyataan yang harus diberikan tanggapan oleh siswa. Pada akhirnya tahap uji coba perorangan dilakukan di kelas XI IPA 3 SMA Negeri 2 Muara Beliti dengan menggunakan 10 soal tes. Instrumen yang digunakan dalam penelitian ini yaitu:

a. Kuesioner atau Angket

Mulyatiningsih (2014) angket atau kuesioner digunakan untuk memperoleh dan mendapatkan data serta mendukung data keaktifan belajar yang dapat diungkap dari diri siswa sendiri. Kuesioner digunakan untuk mendapatkan data tentang kelayakan bahan ajar berupa buku fisika. kuesioner tersebut diperuntukkan bagi ahli materi, ahli grafis, ahli tata bahasa, serta pembelajaran fisika, dan guru fisika. Kuesioner ini juga digunakan untuk merekam dan melihat respon siswa saat proses uji coba produk dilakukan. Dalam hal ini lembar yang digunakan berupa angket respon siswa yang berisi pertanyaan untuk merekam dan merlihat respon siswa terhadap buku fisika yang dikembangkan. Instrumen ini terlebih dahulu di validasi oleh ahli.

b. Buku

Buku yang akan dikembangkan berupa buku fisika berbasis kontekstual pada materi medan magnetik. Buku ini yang akan dikembangkan disesuaikan dengan sintaks tersebut dan akan di uji cobakan valid dan praktis, serta buku ini akan di validasi dan revisi dengan ahli pakar nantinya.

Teknik analisis data yang gunakan dalam penelitian ini yaitu:

a. Analisis Kelayakan dan Respon Siswa Terhadap Buku Ajar

Puplished at https://ojs.stkippgri-lubuklinggau.ac.id/index.php/SJPIF 
Teknik analisis data untuk kelayakan buku ajar fisika berbasis kontekstual dan respon siswa terhadap buku ajar fisika berbasis kontekstual dilakukan dengan menganalisis angket atau kuesioner yang diberikan peneliti. Lembar angket kelayakan buku ajar tersebut direkam menggunakan instrumen lembar uji coba. Angket ini juga digunakan untuk merekam respon siswa saat proses uji coba produk dilakukan. Penyusunan angket telah dilakukan berdasarkan kisi-kisi, instrumen angket disusun dengan menggunakan skala likert tipe 4 dan sebelum digunakan angket telah dikoreksi terlebih dahulu oleh ahli. Respon direkam menggunakan instrumen angket respon siswa. Tujuan utama angket ini adalah untuk mengetahui respon siswa dan untuk menentukan kepraktisan buku ajar fisika berbasis kontekstual pada materi medan magnetik di SMA Negeri 2 Muara Beliti pada semester ganjil pada pelaksanaan uji perorangan. Widoyoko (2019) menyatakan bahwa skor yang telah ditetapkan dapat dihitung dengan menggunakan rumusan sebagai berikut:

Tabel 1. Aturan Pemberian Skor Angket Respon

\begin{tabular}{cc}
\hline Kategori & Skor \\
\hline Sangat Kurang & 1 \\
Kurang & 2 \\
Baik & 3 \\
Sangat Baik & 4 \\
\hline
\end{tabular}

Analisis rerata dilakukan pada angket respon kepraktisan dengan langkah-langkah sebagai berikut Widoyoko (2019) :

1. Menghitung nilai rerata skor tiap butir instrumen

2. Menghitung nilai rerata skor tiao komponen

3. Membandingkan nilai rerata skor tiap komponen dengan kriteria

Tabel 2. Aturan Pemberian Skor

\begin{tabular}{clcc}
\hline No & Aturan Pemberian Skor & Respon positif & Respon negatif \\
\hline 1 & Sangat kurang & 0 & 1 \\
2 & Sangat baik & 1 & 0 \\
\hline
\end{tabular}

Tabel 3. Kriteria Kepraktisan Buku Ajar

\begin{tabular}{cccc}
\hline No & Rentang skor (i) & Nilai & Kategori \\
& & & \\
\hline 1 & $\mathrm{X}>\bar{x} i+1,8 \times \mathrm{Sb} i$ & $\mathrm{~A}$ & Sangat baik \\
2 & $\bar{x} i+0,60 \mathrm{Sb} i<\mathrm{X} \leq \overline{\mathrm{x}} \mathrm{i}+1,8 \times \mathrm{Sb} i$ & $\mathrm{~B}$ & Baik \\
3 & $\bar{x} i-0,60 \times \mathrm{Sb} i<\mathrm{X} \leq \bar{x} i+60 \mathrm{Sb} i$ & $\mathrm{C}$ & Kurang \\
4 & $X \leq \bar{X} i-0,6 \times \mathrm{Sb}_{\mathrm{i}}$ & $\mathrm{D}$ & Sangat Kurang \\
\hline
\end{tabular}

Keterangan:

$\mathrm{X}=$ skor aktual (skor yang dicapai) 
$\bar{x} l=$ rerata skor ideal

$=\left(\frac{1}{2}\right)$ (skor tertinggi ideal - skor terendah ideal $)$

$\mathrm{SB} i=$ simpangan baku skor ideal $=\left(\frac{1}{2}\right)\left(\frac{1}{3}\right)$ (skor tertinggi - skor terenda ideal $)$

Skor tertinggi ideal $=\sum$ butir kriteria $\mathrm{x}$ skor tertinggi

Skor terendah ideal $=\sum$ butir kriteria $\mathrm{x}$ skor terendah

b. Analisis ketercapaian ketuntasan hasil belajar kognitif pada uji coba perorangan

Untuk ketercapaian ketuntasan hasil belajar kognitif siswa pada uji coba perorangan dilihat dari skor akumulasi (skor akhir) yang diperoleh setiap siswa dalam mengerjakan soal uji kompetensi yang telah disiapkan dalam buku ajar fisika berbasis kontekstual. Kemudian hasil dari skor akumulasi dibandingkan dengan nilai KKM (kriteria ketuntasan minimal) sekolah SMA Negeri 2 Muara Beliti sebesar 75, skor akhir yang diperoleh oleh siswa untuk melihat kriteria kepraktisan dari buku ajar berbasis kontekstual.

\section{HASIL DAN PEMBAHASAN}

Penelitian dilakukan pada siswa kelas XI IPA 3 di MA Negeri 2 Muara Beliti yang dilaksanakan pada tanggal 21 Juli 2020 sampai 26 Iuli 2020 yang melibatkan 27 siswa, terdiri atas 12 siswa laki-laki dan 15 siswa perempuan.

a. Validasi

Hasil penilaian validator terhadap kualitas buku berbasis kontekstual pada komponen kelayakan materi validasi ahli materi dosen fisika memperoleh skror sebesar 42 dan validasi materi guru fisika SMA skor sebesar 46 sementara itu untuk komponen media skor sebersar 35 dan untuk komponen kebahasaan skor sebesar 18. Skor rata-rata keseluruhan komponen validasi adalah 35,25 sehingga buku berbasi kontekstual dikatakan valid dan memenuhi kriteria sangat baik. Sebagai berikut:

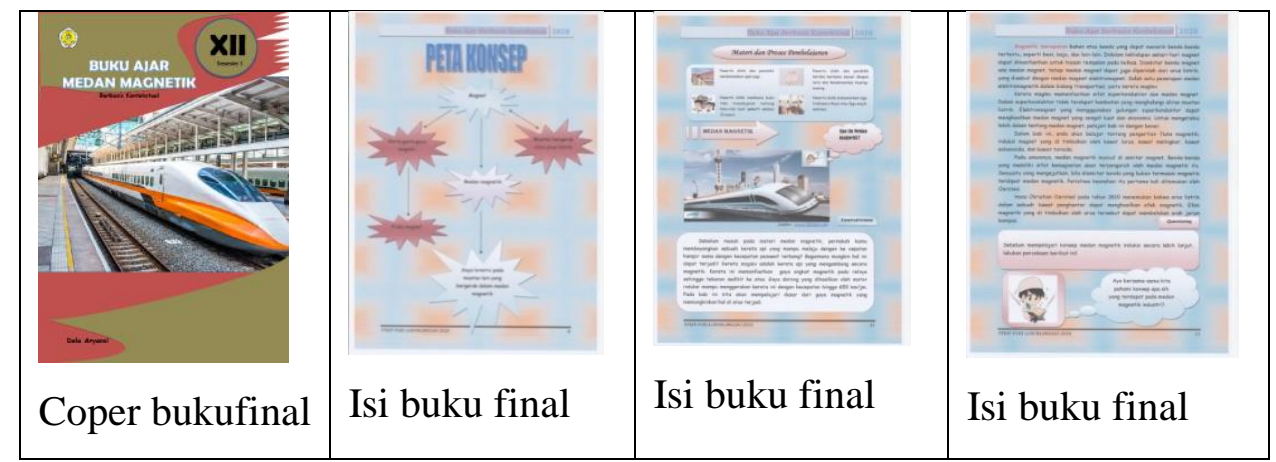

Gambar 2. Modul final yang telah divalidasi 


\section{b. Respon Siswa Terhadap Kepraktisan Buku}

Pada tahap uji coba perorangan buku berbasis kontekstual didapat hasil dari pelaksanaan tahap uji coba perorangan bahwa tidak ada masukan maupun perbaikan dari yang disarankan, sehingga buku dapat digunakan untuk tahap selanjutnya tanpa revisi yang akan diuji kepraktisannya dalam uji coba perorangan. Skor yang diperoleh dari hasil uji coba perorangan didapatkan rata-rata skor sebesar 3,7 yang termasuk ke dalam kategori sangat setuju. Dari hasil uji coba peroranga telah dilakukan didapatkan hasil yaitu bahwa buku yang dikembangkan sudah baik, menarik dan bagus. Namun terdapat masukan dari siswa bahwa siswa tidak setuju karena jika kita sudah mempelajari materinya mudah untuk kita menjawab soalnya. Berikut hasil revisi buku yang dikembangkan berbasis berbasis kontekstual materi medan magnetik berdasarkan masukan dari siswa. Skor yang diperoleh dari hasil uji coba perorangan didapatkan sebesar 3,7 yang termasuk ke dalam kategori sangat setuju.

Buku ajar yang dikembangkan terdapat model pembelajaran yang diterapkan yaitu berbasis kontekstual. Menurut Rahman (2010) menyatakan bahwa pembelajaran CTL merupakan suatu konsep belajar dimana seorang guru menghadirkan dunia nyata kedalam kelas dan mendorong peserta didik untuk membuat suatu hubungan antara pengetahuan yang dimilikinya dengan penerapannya dalam kehidupan sehari-hari, sementara peserta didik akan memperoleh pengetahuan serta keterampilan dari konteks yang terbatasi sedikit demi sedikit dan dari proses mengkonstruksi sendiri sebagai bekal untuk peserta didik dalam memecahkan suatu masalah dalam kehidupannya sebagai anggota masyarakat. Buku ajar yang dikembangkan dibuat menjadi dua macam yaitu buku ajar guru dan buku ajar siswa. Buku ajar yang dikembangkan didesain dengan menggunakan aplikasi ms word, photoshop, dan photoschape. Buku ajar ini didesain sebagaimana mestinya menggunakan cover depan serta cover belakang. Pada tampilan cover buku ajar harus sesuai dengan materi yang akan disajikan serta terlihat menarik. Pada saat mendesain cover dari buku ajar ini terjadi penambahan kalimat pada saat Validasi, namun tidak pada uji coba.

Buku ajar fisika berbasis kontekstual ini sudah baik untuk digunakan. Buku ajar fisika berbasis kontekstual ini dapat membantu peserta didik dalam proses belajar karena soal yang terdapat didalam buku ajar tersebut terdapat soal uji kompetensi, buku ajar tersebut juga dapat memotivasi peserta didik untuk berperan aktif dalam kegiatan pembelajaran sehingga dapat ketuntasan hasil belajar peserta didik.

Untuk melihat kelayakan buku ajar yang dikembangkan, maka perlu diadakannya proses validasi. Ada 3 aspek yang divalidasi yaitu materi, tata bahasa dan media. Hasil validasi 
materi yang diperoleh dari dosen ahli materi sebesar 42, validasi ahli materi guru SMA sebesar 46, semantara validasi ahli bahasa 18 dan validasi ahli media 35. Dari hasil validasi secara keseluruhan sudah valid, dengan rata-rata skor sebesar 37 termasuk kedalam kategori sangat baik. Desain produk yang telah dibuat dan divalidasi dilakukan uji coba perorangan. Dalam hal ini, peneliti melihat kepraktisan dari buku ajar peserta didik setelah menggunakan buku ajar fisika berbasis kontekstual.

Uji coba perorangan dilakukan untuk melihat tingkat kepraktisan buku ajar yang dikembangkan. Dari hasil penelitian yang dilakukan bahwa pada saat uji coba perorangan respon siswa terhadap kepraktisan buku ajar tersebut sangat setuju, komentar di dalam angket respon juga tidak terdapat komentar yang negatif. Komentar berisian persetujuan terhadap pernyataan yang ada di dalam angket reson kepraktisan buku ajar tersebut. Hasil angket yang telah diisi oleh enam peserta didik tersebut mendapatkan rata-rata skor 37 yang termasuk kedalam kategori sangat setuju. Pada tahap ini tidak ada perbaikan atau revisi sehingga penelitian dapat hasil dari angket kepraktisan terhadap buku ajar yang dikembangkan didapat skor sebesar 37 dan termasuk kedalam kategori sangat setuju. Hasil belajar kognitif peserta didik yang dilihat dalam penelitian ini yaitu kepraktisan dari buku ajar yang dikembangkan. Pada saat pelaksanaan uji coba perorangan berjalan dengan lancar dan baik namun tetap terdapat beberapa kendala mengenai jaringan internet yang digunakan, akan tetapi peserta didik tetap dapat mengikuti penelitian dengan baik dan penuh antusias melalui pembelajaran daring. Dari penjelasan tersebut dapat dikatakan bahwa Buku ajar fisika berbasis konekstual pada materi medan magnetik di kelas XII IPA 3 SMA Negeri 2 Muara Beliti dapat dikatakan valid, dan praktis.

Dari penjelasan di atas dapat disimpulkan Bahwa Buku Fisika Aajar Berbasis Kontekstual pada Materi Medan Magnetik Di Kelas XII IPA SMA Negeri 2 Muara Beliti dapat dikatakan valid dan praktis. Seperti yang dikemukakan oleh Darman, dkk (2017) dalam penelitiannya yang berjudul pengembangan buku kerja fisika berbasis kontekstual pada konsep suhu dan kalor untuk pembelajaran fisika memiliki nilai kevalidan 3,50 dengan kriteria sangat valid. untuk tingkat kepraktisan, memiliki kategori praktis dan sangat praktis, memiliki katagori praktis dan sangat praktis menurut guru dan siswa dengan presentase 87\% dan 90\% siswa kelas VII SMP Negeri 2 Kecamatan Payakumbuh. Hal ini sejalan dengan penelitian yang telah dilakukan oleh Azizah (2019) mengungkapkan bahwa pengembangan buku kerja media pembelajaran IPA berbasis kontekstual sebagai penunjang mata kuliah media pembelajaran berdasarkan hasil penelitian di dapatlah hasil validasi aspek materi $96 \%$ 
dan desain memperoleh rata-rata presentase $98 \%$ dengan katagori sangat layak sehingga buku kerja media pembelajaran IPA berbasis kontekstual dapat digunakan. Sedangkan Mendapatkan hasil bahwa buku yang dikembangkan telah valid dan praktis serta berkualitas untuk digunakan pada proses belajar mengajar. buku yang dikembangkan tersebut dapat diterima dengan baik oleh peserta didik, hal tersebut terlihat dari hasil respon peserta didik yang baik. Maka dapat dikaitkan bahwa antara penelitian yang dilakukan dengan hasil penelitian yang dilakukan oleh Darma, dkk mendapatkan hasil bahwa buku ajar fisika berbasis kontekstual baik digunakan pada proses pembelajaran.

\section{KESIMPULAN}

Berdasarkan penelitian yang telah dilakukan, peneliti menyimpulkan bahwa:

1. Peneliti melakukan pengembangan buku ajar fisika berbasis kontekstual pada materi medan magnetik. Peneliti menggunakan model pengembangan ADDIE yang terdiri dari 5 tahapan mulai dari kontruktivisme (contructivism), menemukan (inquiry), bertanya (questioning), masyarakat belajar (learning community), pemodelan (modelling), refleksi (reflection), dan penilaian yang sebenarnya (authenthic assesment).

2. Buku ajar fisika berbasis kontekstual yang dikembangkan mendapatkan hasil penilaian validator pada komponen kelayakan materi mempunyai skor 42 dari dosen ahli fisika dan 46 dari guru fisika SMA, sementara pada komponen media mempunyai skor sebesar 35, dan pada komponen tata bahasa mempunyai skor sebesar 18. Skor keseluruhan komponen yaitu sebesar 35,25 sehingga buku ajar fisika berbasis kontekstual dapat dikatakan valid serta memenuhi kriteria yang sangat baik. Oleh sebab itu, buku ajar fisika berbasis kontekstual pada materi medan magnetik dapat dikatakan valid, dan praktis.

\section{DAFTAR PUSTAKA}

Ariani, T. (2017). Pembelajaran Kooperatif Tipe Team Assisted Individualization (TAI): Dampak Terhadap Hasil Belajar Fisika Siswa. Jurnal Ilmiah Pendidikan Fisika AlBiRuNi, 6(2), 169-177.

Ariani, T., \& Yolanda, Y. (2019). Effectiveness of Physics Teaching Material Based on Contextual Static Fluid Material. Kasuari: Physics Education Journal (KPEJ), 2(2), 7081.

Arini, W., \& Lovisia, E. (2019). Respon Siswa Terhadap Media Pembelajaran Alat Pirolisis Sampah Plastik Berbasis Lingkungan Di Smp Kabupaten Musi Rawas. THABIEA: JOURNAL OF NATURAL SCIENCE TEACHING, 2(2), 95-104. 
Khairunnisa, dkk. (2016). Pengembangan LKS Berbasis Problem Based Learning Bermuatan Sikap Spiritual Pada Materi Pengukuran Untuk Meningkatkan Kemampuan Berpikir Kritis Siswa. Jurnal Ilmiah Mahasiswa (JIM) Pendidikan Fisika 1 (4), 284-291.

Mulyatiningsih, E. (2014). Metode Penelitian Terapan Bidang Pendidikan. Bandung: Alfabeta.

Prastowo, A. (2014). Pengembangan Bahan Ajar Tematik: Tinjauan Teoritis dan Praktis. Jakarta: Kencana Prenada Media.

Rerung, N., Sinon, I., L.S., \& Widyaningsih, S., W. (2017). Penerapan Model Pembelajaran Problem Based Learning (Pbl) Untuk Meningkatkan Hasil Belajar Peserta Didik Sma Pada Materi Usaha Dan Energi. Jurnal Ilmiah Pendidikan Fisika Al-BiRuNi 06 (1), 47 55 .

Sugiyono. (2011). Metode Penelitian Pendidikan Pendekatan Kuantitatif, Kualitatif, dan $R \& D$. Bandung: Alfabeta.

Widoyoko.(2019). Evaluasi program pembelajaran. Yogyakarta: Pustaka Pelajar. 